\title{
Sprawozdanie z prac w Bibliotece Polskiej w Paryżu w 2016 r.
}

W trakcie miesięcznego pobytu w Bibliotece Polskiej w Paryżu (29 czerwca - 30 lipca 2016 r.) kontynuowałem rozpoczęte wcześniej opracowywanie spuścizny Franciszka Pułaskiego, dyrektora Biblioteki w latach 1926-1956 ${ }^{1}$.

Ze względu na to, że w trakcie poprzednich pobytów zinwentaryzowano i skatalogowano prawie całość zespołu, prace wykonywane obecnie miały charakter prac wykończeniowych i redakcyjnych. Sygnatury tymczasowe akt zostały zmienione na ostateczne (BPP 2557-2646). Łącznie spuścizna liczy 90 j.a. i obejmuje 2,20 mb archiwaliów z lat (1919-1925) 1926-1956 (1957). Opracowany katalog wymaga jeszcze drobnych prac redakcyjnych.

Ponadto uporządkowałem niewielki, składający się z 3 j.a. i obejmujący 0,06 mb zespół akt Uniwersytetu Polskiego Zagranicą w Paryżu, wydzielony z ww. spuścizny (w aktach F. Pułaskiego pozostawiono jedynie dublety materiałów z tego zespołu), także i tym materiałom nadane zostały ostateczne sygnatury katalogowe (BPP 2647-2649).

Wiesław Filipczyk Archiwum Narodowe w Krakowie

${ }^{1}$ Relacje z wcześniejszych prac zob. „Krakowski Rocznik Archiwalny” 2009, t. 15, s. 226-227; 2012, t. 18, s. 190-191; 2014, t. 20, s. 166; 2015, t. 21, s. 216. 